\title{
Understanding The Radicalism Movement In Indonesia: A Conflict Approach To The Rise of Terrorism
}

\author{
Nurul Solihin \\ Syari'ah Faculty of IAIN Imam Bonjol Padang, Indonesia \\ E-mail: solihin_nurul@yahoo.com
}

\begin{abstract}
Understanding the Radicalism Movement in Indonesia: a Conflict Approach to the Rise of Terrorism. This study will describe the genealogy, reason, and patterns of salafism movement in Indonesia. The reason why this study seeks to understand the theme because the movement of salafism in Indonesia has emerged dramatically. It can be understood from the acts of terrorism that occurred. There are at least 4 acts of terrorism in 2000; 3 acts of terrorism in 2001; And 1 acts of terrorism in the 2000 Bali bombing which Is the most dramatic act of terrorism and the bombing action at J.W. Marriot hotel in 2003. These acts of terrorism are facts which suggest that the movement of salafism flourished in Indonesia. The data also encourages the study of why terrorism appears in Indonesia? What are the reasons? What is the root of the movement of salafism in Indonesia? The questions above are the research questions. And it all comes from the research paradigm chosen in this study, which is the paradigm of conflict. Assuming that acts of terrorism can be understood as a conflict process. It is not a single process that is the complete reason why terrorism arises, especially in Indonesia. The perspective of Marxism is considered quite possible to explain the factors causing terrorist acts and the growing of the network in Indonesia. Actually, by using the paradigm of conflict; Violence, and horror acts perpetrated by terrorist networks can be detected why such malicious acts occurred in Indonesia. To analyze the data, this study uses the interpretative method. And it's a concern to analyze the conflict between salafism, and others. This process allows the conclusion that the causal factor is the difference in doctrine between terrorism and the others-state, and the notion of neo-liberalism.
\end{abstract}

Keywords: Religious Radicalism, Jihad, Terrorism

\section{Introduction}

In Indonesia, the dynamics of the Islamic movement are becoming clearer with the emergence of radicalism. Thus, radicalism is an

AJIS : Academic Journal of Islamic Studies vol. 2, no. 1, 2017

Postgraduate of STAIN Curup - Bengkulu | p-ISSN 2580-3174, e-ISSN 2580-3190 Available online: http://journal.staincurup.ac.id/index.php/AJIS 
interesting actual issue to study. Why not, Islamic radicalism always turns, transforming their movement into new forms according to the socio-political context that grows in Indonesia. To understand the radicalism of Islam seems possible by reading, understanding the history of Islamic radicalism in Indonesia. The history of radicalism in Islam can be seen at least from several phases. In the pre-reform era, the Islamic radical movement was a movement against the structure of global capitalism and the hegemony of Islam. Now, that has changed, or has transformed into a form of political structure movement. In this form, Islamic radicalism has become a political process, but uses the Islamic symbols to purify their movement. In fact, in addition to the structural movement, Islamic radicalism also declares itself as a cultural movement like da'wah movement. The reason why Islamic radicalism is building, or plunging itself into a cultural movement; None other than to gain the trust of the people, especially the Muslims. At the other end, the effects of the radicalism movement in Indonesia can be seen from acts of terrorism in several places in Indonesia. From the action it may seem to understand the pattern, and the type of movement which they construct.

From an online newspaper, there are at least seven terrorism networks that threaten Indonesia as a nation ${ }^{1}$. They are the Tandzim Qoidatul Jihad commanded by Abu Tholut; The old version of the Jama'ah Islamiyah led by Abu Fatih; Abu Rosyid in Serpong; Abu Omar's network in Solo-Cirebon; Faction Anjengan Masduki-Darul Islam; Darul Islam version of Ajengan Tahmid; Kompak (Committee for Crisis Response) in Ambon. But, Abu Omar's network is the most dangerous group than any other group. Why not, he has many networks. Despite the many networks of terrorism in Indonesia, the actions which they build, and show are relatively mono-patterned. This standpoint is relevant when there are many bombings-suicide bombings, or covert attacks, and terror. That condition encourages the acts of terrorism into a very serious issue in Indonesia. In fact, several bomb blasts since the fall of the Orde baru until October 2005 have shown that terrorism is an ongoing threat 2 . Ironically, in Indonesia targets of terrorist attacks are non-Muslim symbols such as

1 Inilah Tujuh Kelompok Teroris yang Mengancam Indonesia, retrived from www.beritajatim.com, accessed August 1, 2012, at 23:59 PM.

2 Sukawarsini Djelantik, Terrorism in Indonesia: The Emergence of West Javanese Terrorist, (East-West Centre Working Pappers, No. 22: 2006), p. 1. 
churches, cafes, and embassies. Presumably in their perspectivereasoning of terrorism-all of the targeted attacks are the common enemy to be fought. With that view, terrorism groups judge the others who are outside their group.

Table 1: Terorist's Action in Indonesia

\begin{tabular}{|c|c|c|}
\hline DATE & ACTIONS & VICTIMS \\
\hline 01-08-2000 & $\begin{array}{l}\text { Bomb explosion at houses of Philipine } \\
\text { Ambassador, Jakarta }\end{array}$ & 3 people are death \\
\hline $13-09-2000$ & Bomb Explosion in Pasar Bursa Jakarta & 15 people are death \\
\hline $24-12-2000$ & $\begin{array}{l}\text { Bomb explosion at any church in Jakarta, } \\
\text { and the other cities. }\end{array}$ & $\begin{array}{l}17 \text { are death, more than } 100 \\
\text { people are bodily injury }\end{array}$ \\
\hline 12-10-2002 & Bali's Bomb; at a cafe in Kuta Beach & $\begin{array}{l}202 \text { are death, more than } \\
100 \text { are bodily injury. }\end{array}$ \\
\hline 05-12-2002 & $\begin{array}{l}\text { Bomb-explosion in McDonald restourant } \\
\text { in Makasar, Sulawesi. }\end{array}$ & 3 people are death. \\
\hline 05-08-2003 & $\begin{array}{l}\text { Bomb attack part } 1 \text { at J.W. Marriot hotel, } \\
\text { Jakarta. }\end{array}$ & $\begin{array}{l}12 \text { people are death, } 150 \text { are } \\
\text { bodily injury. }\end{array}$ \\
\hline 10-01-2004 & $\begin{array}{l}\text { Bomb-explosion at Sampodo Cafe in } \\
\text { Palopo, Sulawesi. }\end{array}$ & 4 are death. \\
\hline 09-09-2004 & $\begin{array}{l}\text { Car bomb, explosion in front of Australia } \\
\text { Embassy, Jakarta. }\end{array}$ & 10 are death. 100 are injury. \\
\hline 13-11-2004 & $\begin{array}{l}\text { Bomb explosion at Police office in } \\
\text { Kendari, Sulawesi. }\end{array}$ & 5 are death, 4 are injury. \\
\hline 28-05-2005 & Bomb attack at Tentena Market, Sulawesi. & $\begin{array}{l}22 \text { are death, } 90 \text { are bodily } \\
\text { injury. }\end{array}$ \\
\hline $31-12-2005$ & Bomb-explosion at Palu market, Sulawesi. & 8 are death, 48 are injury. \\
\hline 01-10-2005 & $\begin{array}{l}\text { Suicide-bomb, in two places-Jimbaran } \\
\text { and Kuta, Bali. }\end{array}$ & $\begin{array}{l}20 \text { are death, } 129 \text { are bodily } \\
\text { injury }\end{array}$ \\
\hline 17-07-2009 & $\begin{array}{l}\text { Bomb J.W. Marriott hotel part-2, and Ritz- } \\
\text { Carlton hotel, Jakarta }\end{array}$ & 9 are death, 42 are injury. \\
\hline
\end{tabular}

From the table above it can be concluded that the action of terorism in Indonesia is growing prosperous. It is not profuse that if many people think Indonesia is a place for terorism act . But this phenomenonin is relatively new in Indonesia. It emerged after the fall of Suharto, when the reform era exploded. Sukawarsini Djelantik wrote that "After the terrorist attacks in Bali in November 2002, the Indonesian government paid serious attention to terrorism prevention issues / policies. Blast bombing by terrorism can be considered as a new phenomenon in Indonesia's 
political $^{3}$. The question relating to this problem is: "In Indonesia, why does terrorism network and its actions grow ironically? "What is the factor of the burden?" And "How is this case understood?" Terrorism is not a spontaneous process, but there is a major factor why terrorism arises in Indonesia. It is appropriate in this research to assume that acts of terrorism are a conflicting process that occurs between terrorist and the others. This assumption will be analyzed based on the Conflict Paradigm, hoping that this approach can give the explanation of why terrorism arises in Indonesia.

\section{Conflict Theory: Ideology, Bombing-Suicide and Terrorism}

What is the relationship between class movements and terrorism? It seems difficult to correlate them, but that may be explained. The explanation, can be understood by the paradigm of conflict. Conflict theories-explaining that conflict and opportunity are inherent in the social world as order and permanence ${ }^{4}$. As if conflict is a natural movement. But that is not that description. Later, it is understood that conflict is driven, caused by the human mind. The terrorism also be driven by a human bitch's mind. Although it is just a phenomenon of "wildness". But in fact, Terrorists seek, creating common enemies that are likely to be attacked. The question is: "How is this case explained?".

Kant and Hegel have explained to us that every human-individual, group, organization, or other unit in society, represents a force that has actions capable of stimulating counterforces ${ }^{5}$. Anyone capable to do acts of terror, it depends on the stimulation, or social factors that cause a person become repressive. Thus, several factors make terrorism appear and make them anarchist like exploitation, discrimination, and economic problems. Actual terrorism represents the existing of social conflicts in society. It became one of the other forms of class struggle. How can this view be understood? Johan Galtung has elaborated the theory of conflict. His views can be studied in his Theories of Conflict: Definition, Dimensions, Negations, Formation. Galtung considered that to represent

3 Sukawarsini Djelantik, Terrorism in Indonesia: The Emergence of West Javanese Terrorist., p. 1.

4 Otomar J. Bartos \& Paul Wehr, Using Conflict Theory, (New York: Cambridge University Press, 2002), p. 12.

5 Ibid 
the conflict theory; At least it can start from two things, actors and their goals ${ }^{6}$. Referring to Galtung's view, conflict theory will not become clear without understanding the two terms-their actors and goals. From this assessment, the relationship between terrorism and class movements at least can be explained.

The actor in conflict theory is an important element. They are the conflict stimulators. From their minds, classes in society are formed, or designed. In this context, Galtung categorizes the actor to "single actor conflict". Galtung explains that the single actor conflict is an actor who always feels weird with himself7. Usually folded person. And unlike groups as actors in conflicts that are societal. And also different from the community as an actor. Each person, group, and community actors have intra and inter-connections. Intra is the same actor with 1 or only one person. While inter, can be more than one person actor ${ }^{8}$. From the diagram, or table below, the actor category can be understood:

Tabel 2: The types of conflict

\begin{tabular}{|l|l|l|l|l|}
\hline \multirow{4}{*}{ Domain } & \multicolumn{4}{|c|}{ Type } \\
\cline { 2 - 5 } & & \multicolumn{1}{|c|}{ Person } & \multicolumn{1}{c|}{ Group } & Society \\
\cline { 2 - 5 } & Intra & Suicide & Apathy & Anomie \\
\cline { 2 - 5 } & Inter & Homicide & Internal War & External war \\
\hline
\end{tabular}

Source: Johan Galtung, Theories of Conflict: Definition, Dimensions, Negations, Formations, (Johan Galtung lectures in Columbia University)

The types of actors (person, group, society) are equally has a capable of making damage. They have in common with the extent of damage they may cause; with terror, or other violence. But, one of the actors has differences in the ability to make damage, and the group as an actor is certainly more dangerous than other actors such as terrorism networks, or Islamic radicalism. At the other hand, in conflict; There are actors structure. Referring to Johan Galtung, that the structure of actors requires a set of elements and a set of relationships among their peers ${ }^{9}$. Generally, it can be assumed that all conflicts are structured. But, that assumption is not entirely as a true premise, or a correct conclusion. The question is:

6 Johan Galtung, Theories of Conflict: Definition, Dimensions, Negations, Formations, (Johan Galtung lectures in Columbia University), p. 39.

7 Ibid., p. 46.

8 Ibid.

9 Ibid., p. 48. 
"What about terrorism?". The assumption, that all conflicts are structured, can be used to analyze the phenomenon of terrorism. In fact, acts of terrorism are a phenomenon of conflict. Referred as a phenomenon of conflict, basically terrorism creates the others or needs them as common enemies, and targets attacks. In order to achieve a targeted goal, terrorist networks often deal with other networks to build strong coalitions.

In many countries, terrorism networks, or terrorist groups have a moral similarity ${ }^{10}$. The morality comes from the belief in the function, and the movement that they believe. They believe that their culprits-terror, or violence-to purify religion, and destroy their enemies like the United States and its coalition. Thus, the structure or the condition of terrorism will become clear as an understanding, by analyzing the case of terrorism with conflict theory. The question is: "What is the theory of the conflict?". Referring to Jörg Rössel \& Randall Collins, that conflict theory is a solution to the problem of micro-macros in sociology ${ }^{11}$. Micro and macro conflict theory is not intended for the separation of social reality, as illustrated by opposing the concepts of actors and systems or agencies and structures. Nevertheless, they represent the spatotemporal segment of social reality ${ }^{12}$. In particular, conflict theory concerns about the relationship between interacting systems. When using conflict theory to analyze the phenomenon of terrorism, it becomes easy to understand that a study, or study seeks to understand the interaction between context and acts of terrorism. ${ }^{13}$ It is important to understand that the interaction between them is derived from their goals, and a common vision of the world or their beliefs.

Galtung's idea of a goal in conflict theory is that a goal is the same as an actor in a scope ${ }^{14}$. Galtung assumes that all actors have a definite capacity in a rule15. It informs us that the wide range of goals that the

1010 Virginia Held, How Terrorism is Wrong: Morality and Political Violence, (New York: Oxford University Press, 2008), p. 13.

11 Jonathan H. Turner (eds)., Handbooks of Sociology and Social Research, (New York: Springer, 2006), p. 509.

12 Ibid.

13 Ibid., p. 510.

14 Johan Galtung, Theories of Conflict.., p. 57.

15 Ibid. 
actor has produced many ideals in conflict situations. The Illustration; There are several different purposes of terrorism in other places. The goal of terrorism in Indonesia is very different from acts of terrorism in other countries, such as in the United States ; Especially the 9/11 attacks. The difference goal between terrorists depends on the situation, and the context in which they design bombing actions. It's all due to the difference in targets, and the intensity of hatred. This phenomena raises a question: "What is the source of the purpose of terrorism?". There are several interpretations related to the source of the purpose of terrorism. And it will become clear by understanding the pattern of terrorist attacks; It is not excessive to understand that the purpose of terrorism comes from the beliefs, or ideologies that nest in their minds. At this level, the function of religion is questionable.

The goal of terrorism

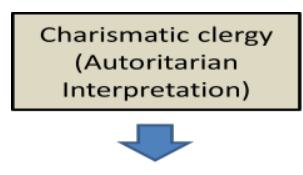

Worldview

(Religion, ideology,

interpretation on

religion doctrine,

and economic problem)

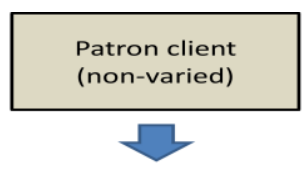

Goal

(Religion Purify,

Build new

goverment and

economic system)

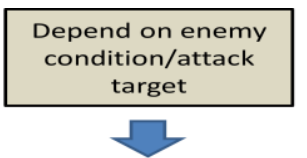

Enemy

(Suicide-bomber, piracy, virus

spreading)

The aim of the terrorists determines the pattern of attacks against common enemies. And the internalization of doctrine is produced, or done by the charismatic clerics in their community who influence a "worldview" believed by the terrorists. From this condition, violence, and acts of terrorism are generated by terrorist organizations in various countries, especially in the United States, or other secular countries. Indeed, the choice of acts of terrorism can be interpreted with the Durkheim-suicide theory. The term of suicide may be a popular act when terrorism applies suicide as a strategy to defeat their enemies. However, there is a clear distinction between ideological suicide (suicide bombing) with social suicide. The question is: "What is the difference?". Emile Durkheim in his Suicide, has explained comprehensively. Durkheim's view informs us that "..suicide is applied to all cases of the deaths directly or indirectly from a positive or negative act of the victim himself, which he 
knows will produce this result ${ }^{16}$. Durkheim's definition of "suicide bombing" may be analyzed by a sociological approach such as Durkheim's project of suicide.

However, there is a common category between social suicide and ideological suicide. Durkheim offers a pretentious term about it . It is "egoistic suicide"; A term that shows that suicide is not a vacuous act, or action without motive. It is caused by some religious, political, economic, social, and even family tendencies. The Durkheim thesis, in a special case, that suicide is caused by religion. This thesis seems acceptable. Although ideally, all religions forbid their followers to commit silly suicide. But Durkheim notes that suicide is specifically driven by religion. His observations have shown a strong correlation between some religions and suicidal actions.

Tabel 3: The Different Religious Confessions Affect Suicide ${ }^{17}$

\begin{tabular}{ll}
\hline & $\begin{array}{l}\text { Average of } \\
\text { suicides per } \\
\text { million } \\
\text { inhabitants }\end{array}$ \\
\hline Protestant states & 190 \\
Mixed states (Protestant and Catholic) & 96 \\
Catholic states & 58 \\
Greek Catholic states & 40 \\
\hline
\end{tabular}

In social context, suicide is generally caused by the physical environment-social-or geographical-elimination of the shelter, or the crisis of water. But the phenomenon of suicide becomes a unique reality, when actors commit suicide involving religious tendencies in their actions. It makes sense to ask the question: "Where is the position of religion in suicide?" In this case, it seems difficult to conclude that religion affects suicide in some places. In fact, it does not seem to make sense. Because all religions never teach their adherents to be apathetic, or frustrated personalities. Such is the paradoxical view. Why not, suicide is not a psychological dilemma. But it sometimes contains religious

16 Emile Durkheim, Suicide: A Study in Sociology, (New York: Routledge, 2005), p. xlii.
17 Ibid., p. 105. 
tendencies. In this context, the phenomenon of terrorism can be understood as an ideological process. How can this view be explained?

The act of terrorism as an ideological process is closely linked to globalization containing a great ideology-Advanced of Capitalism, or NeoLiberalism. Referring to Mohamad Faisol Keling, Md. Shukri Shuib, Mohd. Na'eim Ajis, \& Achmad Dzariean Mohd. Nadzri stated That the current violence is a phenomenon caused by specific individuals or groups to obtain objective certainty ${ }^{18}$. The word "a certain objective" is a sign that informs us that the phenomenon of terrorism is an ideological process. How is that rationalized? The main question that might explain it is: "Is that ideology?". stated from Terry Eagleton's view in his Ideology: An Introduction, the word "ideology" is a text, composed of several different network of concepts; Devised by distorted history, and it is perhaps more important to judge what is of value ${ }^{19}$. In other forms, there are several ideological meanings: a) The process of generating meaning, signs and values in social life; B) a building whether the characteristics of specific social group or class ideas; C) ideas that help to legitimize a dominant political force; E) Communication systematically distorted; F) something that provides a position for a subject; G) thoughts that are motivated by social interests; H) the identity of thought; I) a socially important illusion; J) alleged discourses and powers; K) a medium for actors with a social consciousness to understand their world; L) Building action-oriented actions of beliefs; M) phenomenal language and reality chaos; N) the basics of semiotics; 0 ) indispensable media for the life of an individual in relation to a social structure; $\mathrm{P}$ ) the process of social life is converted into a natural reality 20 .

The exact ideological meaning that has been narrated above, and having a context with terrorists is the point " $d$ " -a wrong idea that helps to legitimize dominative political forces. In fact, terrorism has consistently relationship with an ideology. This view can be detected from the signs used by terrorism in their actions. Constantly, after the

${ }^{18}$ Mohamad Faisol Keling, Md. Shukri Shuib, Mohd. Na'eim Ajis, \& Achmad Dzariean Mohd. Nadzri, The Problem of Terrorism in Southeast Asia, (Journal of Asia Pacific Studies (2009): Vol 1, No 1), p. 28.

19Terry Eagleton, Ideology: An Introduction, (London: Verso, 1991), p. 1.

20 Ibid. 
terrorists complete their acts of terror, they usually leave some messages directed at their enemies. The messages consist of those designed with changing types such as videos, handwriting, or emails sent to their enemies. Thus, ideologies believed by terrorism are various sets of beliefs that are motivated by the interests of the group21. Named as "motivated by group interest", not with "non-social interest", it proves that terrorism believes in ideology to teach their doctrine, and forces the others to accept the ideology. In the Islamic political movement, terrorism has a tough character against other ideologies that are not Islamic ideologiesCapitalism and Neo-Liberalism. Counter-terrorism opposition to nonIslamic ideology can be found in the writings of Salafi-Muslim Ideologists such as Sayyid Qutb, Hassan al-Banna-Ikhwan al-Muslimin, Maulana Abu'l a'la Maududi in the 1930s, 1940s, or 1950s22. Some terrorists make a religious understanding of their thinking (read, Muslim salafi). Ironically, they make that thought an important part of their actions. In fact, they believe that their religious understanding is the correct interpretation. Meanwhile, other interpretations are wrong, and the wrong doctrine for them must be abolished. In this process then the view of terrorism becomes an unchanging ideological and ideological viewpoint.

Jihadism is one of the doctrines of terrorism resulting from a false interpretation of the concept of jihad in Islam. That can be seen from the tragic attack in September 2001. It has made the United States declare "Global War on Terrorism" 23 . The war was probably done by a premature organization that never had power, or a clear ideology. It becomes a rational decision, when the United States sees that terrorism networks are a global enemy that should be fought. There are at least four radical religious organizations-Hezbollah, Hamas, Taliban, and Laskar Mahdi. This fact leads to a global consensus, that combating such radical organizations is the obligation of all countries. But the global community forgets that beyond the purpose of terrorism, there is a dangerous ideology that is not friendly for consumption by developing countries, or third countries. It is global capitalism, and neo-liberalism.

21 Ibid., p. 2.

22 Tahir Abbas (eds), Islamic Political Radicalism: A European Perspective, (Edinburgh: Edinburgh University Press. Ltd, 2007), p. 4.

2323 Eli Berman, Radical Religious and Violent: The New Economics of Terrorism, (London: The MIT Press, 2009), p. 1. 
Tabel 3: Socio-economic indicators in several the country ${ }^{24}$

\begin{tabular}{|c|c|c|c|c|c|}
\hline Nations & PPP_L1 $10 \%{ }^{a}$ & $\begin{array}{l}\text { Gender } \\
\text { Equity }^{b}\end{array}$ & $\begin{array}{l}\text { Health \& } \\
\text { population }\end{array}$ & Knowledge ${ }^{d}$ & $\begin{array}{c}\text { Peace and } \\
\text { Order }^{\circ}\end{array}$ \\
\hline \multicolumn{6}{|c|}{ Less Developed Countries } \\
\hline Afghanistan & - & 14 & 9 & $\mathbf{8}$ & 4 \\
\hline Comoros & — & 46 & 24 & $\mathbf{8}$ & 40 \\
\hline Egypt & 1522 & 30 & 45 & 49 & 78 \\
\hline Kenya & 182 & 39 & 20 & 14 & 35 \\
\hline Kurwait & - & 27 & 55 & 52 & 37 \\
\hline Lebanon & - & 40 & 53 & 59 & 19 \\
\hline Libya & - & 58 & 36 & 54 & 40 \\
\hline Pakistan & 763 & 28 & 21 & 13 & 17 \\
\hline Saudi Arabia & - & 36 & 16 & 38 & 21 \\
\hline Tanzania & 140 & 46 & 16 & 6 & 63 \\
\hline Average & 652 & 39 & 32 & 33 & 39 \\
\hline \multicolumn{6}{|c|}{ Mane Developed Countries } \\
\hline Canada & 7123 & 66 & 86 & 95 & 72 \\
\hline France & 6446 & 59 & 88 & 86 & 69 \\
\hline Germany & 7758 & 66 & 83 & 85 & 75 \\
\hline Japan & 12082 & 44 & 91 & 93 & 92 \\
\hline italy & 7700 & 53 & 87 & 84 & 79 \\
\hline Norway & 11537 & 74 & 85 & 91 & 77 \\
\hline United'States & 5744 & 58 & 82 & 94 & 58 \\
\hline Average & 8341 & 60 & 86 & 90 & 75 \\
\hline
\end{tabular}

The table above illustrates the global "gap" between Muslim countries, and other non-Muslim countries. After that, The question arises : "Why the economic gap, and the quality of life that is so clear today? Some terrorist groups have concluded that the underlying cause of the Muslim state is the ownership of welfare machinery of exploitation-by non-Muslim countries. None other than Capitalism, and Neo-Liberalism. In fact, Capitalism and Neo-Liberalism were able to exploit Muslim countries. Ironically, the Muslim country has never realized that. In this context, in fact the terrorist movement is worthy of being understood as part of the class movement, and the ideological movement that seeks to resist Capitalism and Neo-Liberalism. Unfortunately, their methods are wrong and heavy to accept.

\section{Understanding the Movement of Islamic Radicalism in Indonesia: Networks, Symbols, and Tendencies}

Islamic radicalism in Indonesia is not a new phenomenon. It has existed since the pre-independence of Indonesia. But the phenomenon reemerged dramatically in the 1990s. At least there are several factors that cause the emergence of it in Indonesia. Martin van Bruinessen, a researcher concerned with the study of Islam-Indonesia has published a paper, Genealogies of Islamic Radicalism in Post-Soeharto Indonesia.

24 Paul R. Ehrlich, \& Jianguo Liu, Some Roots of Terrorism, (Journal of Population and Environment, Vol. 24, No. 2: November-2002), p. 186. 
Bruinessen writes that the emergence of hard-line Muslims has pushed up a jihadist discourse and mobilized its followers to fight jihad in an area where there was an inter-religious conflict, such as Maluku or Poso in Central Sulawesi. This is one of the new phenomena of contemporary Indonesian Islam ${ }^{25}$.

Grafik 1. Terorism in Indonesia, 1970-200726

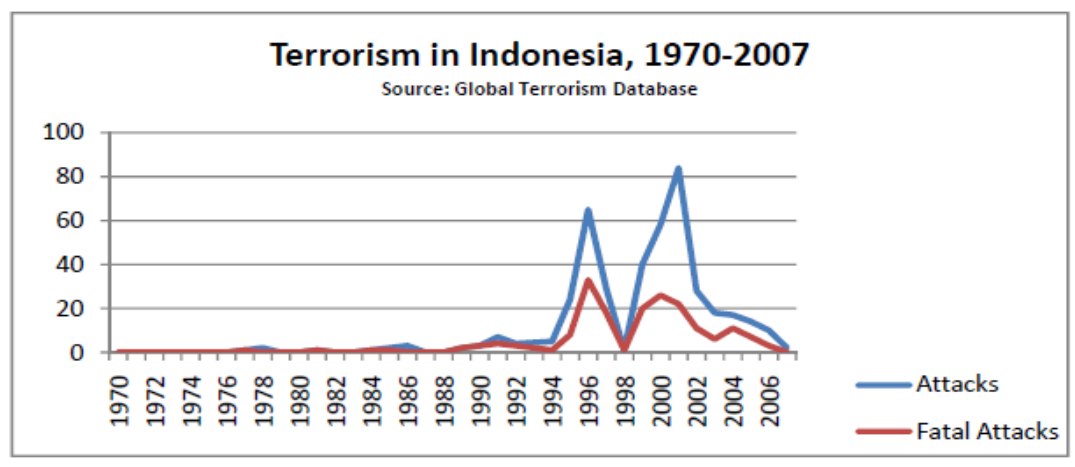

The graph above illustrates that terrorism attacks increased in 1994 to 2002, and fatal attacks also occurred during the same period. This is an interesting case. Seen as an interesting case, because the phenomenon of terrorism develops when Indonesia is transforming into a new era-of reform. Whereas, the function of Islam in Indonesia, especially in the case of Indonesia's deceitful efforts is noted as an important force, and the judgment can be proved or read from the history of Indonesia "how the scholars shoulder to fight against Dutch colonialism and Japanese colonialism. Bruinessen sees that the roots of terrorism in Indonesia can be traced, traced back to the pre-independence era. Since that era, Islamic organizations have grown up and participated in various wars against the colonial. Martin van Bruinessen noted during the Japanese occupation (1942-45), Indonesian Muslims have been politicized. Scholars are given a literary and political education: all Muslim organizations are pushed under the umbrella of the Masjumi organization, which in the war of independence has become a political party. ${ }^{27}$

25 Martin van Brunessen, Genealogies of Islamic Radicalism in post-Suharto Indonesia, (South Asia Research Journals, Vol. 10, No. 2: 2000), p. 117.

26 National Consortium for the Study of Terrorism and Responses to Terrorism, Press Release, July 17, 2009.

27 Martin van Bruinessen, Genealogies of Islamic Radicalism in post-Suharto.., p. 120. 
On the day when Japan was conquered, August 8, 1945; Radical youth groups forced Soekarno-Hatta to declare the independence of Indonesia ${ }^{28}$. But the Dutch attempt to revive and reinforce power has involved tyrannical power. It made the clerics declare jihad, and the Muslim militan often led by the clerics played an important role in the fight for independence ${ }^{29}$. The participation of Muslim militan for Indonesian independence is marked that Muslim organizations in Indonesia have strong principles, and a strong commitment to Indonesian independence. They were willing to go to war with the colonials; The spirit of jihad is the energy of war that legitimizes the killing of common enemies like the Netherlands and Japan. Both are colonialism. They must be abolished from the archipelago, this is the belief of Muslim organizations, and principles. The snippet is not the end of the story of Muslim participation and their clarity in Indonesian history.

After Indonesian independence was obtained from the Netherlands on August 17, 1945, the important role of Muslim organizations is continued. This is evidenced by the participation of Muslim organizations in important events in Indonesia. In fact, the radical character of Muslim organizations can be detected from the rejection of Muslim radical organizations affiliated with the Republic of Indonesia. They are the Kartosuwiryo group. Kartosuwiryo declared the Darul Islam (DI / TII) movement, or the Islamic state of Indonesia ${ }^{30}$. What was the reason DI / TII declared an Islamic State, and rebelled against the Indonesian government? The contributing factor is that the Republic of Indonesia voluntarily makes the foundation of the state outside the basics of Islam as the foundation of the Pancasila-state. This then prompted Kartosuwiryo and his followers against, and rebelled against the Sukarno government. DI / TII is a serious contender for the Government of the Republic of Indonesia and becomes a challenge, even barriers after independence are achieved 31 . Another thing, the emergence of Indonesia as a sovereign nation, not ending various dilemmas. Even Indonesia after that was at the edge of the split horn.

\footnotetext{
28 Ibid.

29 Ibid.

30 Ibid.

31 Ibid.
} 
The rebellion movement in various provinces - South Sulawesi, joined to the Darul Islam movement. The reasons for this movement differ from one another, but all agree that the state ideally is based on Shari'a ${ }^{32}$. It made the republican government-Sukarno-to be worried about the nation's split. This movement is an elite rebellion. Another word, it is called political Islam; A movement declared by the Elite Muslims to oppose secular politics, or secular ideologies that influence the political structure of the Republic of Indonesia. At least it can be concluded that the roots of radicalism in Indonesia emerged since Indonesia existed, those who sought to achieve independence status from colinialism. In fact, Political Islam has become a pillar of Indonesia's democratic transition, in the sense that it has promoted the catalyzing of civil society and political elections ${ }^{33}$. In fact, the participation of Muslims in politics can be traced from the dynamics of Muslim elite relations with government-bureaucrats.

Interestingly, the relationship is in harmony with the rise of Politics Islam. An episode of Extremist-Muslim emergence in Indonesia. They participate, or encourage, the dynamics of Indonesian Islam. Indeed, this movement is not something unique or foreign. Why is that? The reason for Islamic radicalism is driven by Muslim Elites, or politicians; Especially when the Japanese-colonial Indonesia from 1942-45, used Islamic elements to counter and infiltrate anti-western sentiments and establish the Office of Religious Affairs, which was given the authority to deal with Islamic issues at the local level ${ }^{34}$. It is a sign that Islamic primodalism is an authentic history of Indonesia's political dynamics and the basis of the birth of sharia-based politics into the Indonesian constitution.

The dynamics became a dramatic thing when Soekarno wanted to establish a secular state and consider minority bases in the archipelag ${ }^{35}$. Finally, Soekarno succeeded in making Pancasila the foundation of the Republic of Indonesia. But never explicitly convey the Shari'a as a pillar of the state in Indonesia. In 1947, DI / TII appeared on the mainland of

32 Ibid., p. 121.

33 Zachary Abusa, Political Islam and Violence in Indonesia, (London \& New York: Routledge, 2007), p.13

34 Ibid., p. 15.

35 Ibid. 
Sunda mountains, West Java ${ }^{36}$. The group is led by the anti-Dutch guerrilla, S.M. Kartosuwiryo. Indeed, this group is the root of Islamic radicalism in Indonesia. How is it rationalized?

The relationship between the Islamic militan in the Old era and Islamic Radicalism in the reform era seems to be traced from their conception of the state and sharia law. Islamic militan-DI / TII-and Islamic radicalism-Jamaah Islamiah believe that sharia law is an absolute pillar to form an Islamic state. On August 7, 1949, Kartosuwiryo declared the Islamic State of Indonesia (NII), and the Islamic state in West Java. Adam Schwartz notes: "By striking Islam as the foundation of the state, [New Nationalist Government] has positioned itself as a crime of the Netherlands and the enemy of Darul Islam ${ }^{37 . " ~ F r o m ~ t h i s ~ p o i n t, ~ t h e ~}$ guerrilla war led by S.M. Kartosuwiryo exploded. In fact, all this made Sukarno angry and want to try to destroy the separatist movement. Soekarno's effort succeeded. DI / TII is destroyed, but its spirit and doctrine are still growing and being inherited. At least that can be traced from Islamic radicalism that grew in the modern era, especially after the period of the Reformation in Indonesia.

Although the Islamic party succeeded in gaining power and influence, but in Muslim extremist views; The Islamic party is still committed to the secular state and democracy38. This condition is the cause of the emergence of Islamic radicalism in the modern era. They are a group that represents that they are anti-western, or anti-Americanism. Merlyn Lim has published a work of Islamic Radicalism and Anti-Americanism in Indonesia: The Role of the Internet. This research describes that Islamic Radicalism and Anti-Americanism movement in Indonesia is a representation of contemporary Muslim extremists in Indonesia. The movement-a movement known as Islamic terrorism, was as strong as President George W. Bush's speech:

The deliberation and the lethal attacks against our country yesterday are more of an act of terror, but it is an act of war. The attack encourages us to unite. Indeed, freedom and democracy are under

\footnotetext{
36 Ibid.

37 Ibid., p. 16.

38 Ibid., p. 37.
} 
attack. It will be a monument to the battle between "virtue" against the evilis.

Bush's statement on Islamic terrorism is a sign that Islam is soon under attack. In other words, the fight against the American symbol is part of jihad. In this context, some bomb attacks in Indonesia are considered as representations of jihad. Indonesia, which is popular as the most populous Muslim nation in the world; Suddenly famous as a country filled with terror attacks and bombs ${ }^{40}$. Greg Fealy describes this reality with: "The Bali bombings in October 2002 and the disclosure of Jemaah Islamiah terrorism network have brought Indonesia into a valley of terrorism. Because Indonesian Islam is famous for its tolerant attitude and character, terrorism in Indonesia becomes strange and mysterious. To understand the reasoning it seems important to analyze the symbols, or doctrines used by terrorism in their actions.

Essentially, terrorism, and the radicalism movement of Indonesia is a complex mixture of "the local" and "international factors", similar to religious mixing, political and economic factors ${ }^{41}$. In the perspective of terrorism, Islam in Indonesia is being suppressed, and marginalized by several elements. It becomes an obstacle for Islam to become the center of national life. In that context, for terrorists, acts of terror are movements to fight for self-esteem-Islamic values and dignity. Thus, it seems that acts of terrorism can be interpreted as an organized attack aimed at generating fear for a group of people-enemies of Islam. Unlike wars, acts of terrorism do not exert systematic action; On a grand scale but rather suddenly unexpectedly, with random targets, and the victims are often civilians ${ }^{42}$. Interestingly, attack targets are symbols that represent the common enemy as well as the WTC that becomes a proverti American representation. Terrorist attacks are markers of a war. This

\footnotetext{
39 Merlyna Lim, Islamic Radicalism and Anti-Americanism in Indonesia: The Role of the Internet, (Washington, D.C: East-West Center Washington, 2005), p. 29.

40 Greg Fealy, \& Aldo Borgu, Local Jihad: Radical Islam and Terrorism in Indonesia, (Australia: Australian Strategic Policy Institute, 2005), p. 11.

41 Greag Fealy, \& Aldo Borgu, Local Jihad..., p. 3.

42 Maslathif Dwi Purnomo, M. Hum., Violence, Extremism and Terrorism in Indonesia: A Case study of Terrorism acts in Indonesia during 2000 until 2011, (IPEDR Vol. 34: 2012), p. 74.

43 Ibid.
} 
view is inferred from the attack pattern, the target of the attack. The attack on WTC (World Trade Center) in New York, USA on September 11, 2001, known as "September Gray", claiming 3000 victims is a sign indicating that terrorism seeks to destroy enemy symbols with variedbombing actions Suicide, and other sadistic acts ${ }^{43}$.

Abu Bakar Ba'asyir is one of the famous scholars as a radical cleric in Indonesia. In fact, Ba'asyor is considered an important actor behind several acts of terrorism in Indonesia. In fact, Ba'asyir legitimizes that acts of terrorism against the enemies of Islam are the right thing to do, and are worth Jihad in Islam. Ba'asyir often uses verses of the Qur'an to legitimize his radicalism. For Muslims, the Qur'an is the supreme source of the law that guides their lives. Not because the Qur'an is the revelation of Allah s.w.t, and there is no gap to doubt it. However, the methods for understanding and interpreting can differ from one to another. Among them are rational, and others are highly scriptural ${ }^{44}$. Where is his position?

Abu Bakar Ba'asyir like Ja'far Umar Thalib is a radical Muslim ${ }^{45}$. His character in interpreting the Qur'an is highly scriptural. This is understandable from his views and interpretations when assessing the United States and its coalition. And Ba'asyir consistently quotes the Qur'an as the basis of the legitimacy of his opinion. The verses of the Qur'an often used by Muslim Radicals-Abu Bakar Ba'asyir, as well as Umar Ja'far Thalib-are:

"Verily We have sent down the Book of the Law in it (there is) a guidance and a light (which illuminates), which by the Book is decided the case of the Jews by prophets who surrendered to God, by their pious people and pastors They are, because they are commanded to keep the books of God and they bear witness against them. Therefore do not be afraid of men, but fear Me. And do not exchange my verses for a small price. Whoever does not decide according to what Allah has revealed, then they are the disbelievers And We have appointed them in it (the Law) that the soul (reciprocated) with the soul, eyes with eyes, nose

44 Greag Fealy \& Aldo Borgu, Local Jihad.., p. 10

45 Saiful Umam, Radical Muslims in Indonesia: The Case of Ja'far Umar Thalib and the Laskar Jihad, (Explorations in Southeast Asian Studies: Vol. 6, No. 1 Spring 2006), p. 2. 
with nose, ears with ears, teeth with teeth, and wounds (was) there kisasnya. Whoever releases his (right of kisas), then releases that right (s) to be a sinner for him. Whoever does not decide the case according to what Allah has revealed, then they are the wrongdoers And We brought their footsteps (the prophets of the Children of Israel) with Jesus son of Mary, justifying the previous Book, namely: the Torah. And We have given him the Gospel in it (there is) a guidance and light (which illuminates), and justifies the previous book, the Torah. And be guidance and instruction for the righteous And let the followers of the gospel decide the matter according to what Allah has revealed in it. Whoever does not decide the matter according to what Allah has revealed, they are the wicked And We have sent down unto thee the Qur'an by bringing the truth, confirming what was before, the books (which were revealed) and the stones against the other books; Then decide their case according to what Allah revealed and do not follow their lusts by abandoning the truth that has come to you. For each of you, We give you clear rules and paths. If Allah willed, He will make you one (only), but Allah will test you for His gift to you, then compete to do good. Only unto Allaah is the Return of all of you, and He is told unto you what ye disputed And decide the matter between them according to what Allah has sent down, and do not follow their lusts. And beware of them, that they may not turn you away from some of the things which Allah hath revealed unto you. If they turn away (from the law Allah has revealed), then know that Allah wills will inflict upon them their lives because of some of their sins. And most of the people are the wicked. ${ }^{46}$

How are the verses used by radical Muslims understood? These verses are called the doctrine of jihad and also as a marker, or symbol used in their actions when attacking the enemies of Islam. Saiful Umam writes, with these verses, Radical Muslim groups believe that jihad is the duty of all Muslims, not only in the sense of self-preservation but also aggressively attacking to enforce the glory of Islam. Meaning, Muslim Radicals and terrorism often quote the Qur'an to sanctify their actions. This process can be understood as an attempt to make the Qur'an a symbol and as the only legitimation of their actions. Beyond that, Islam

${ }^{46}$ Q.S. al-Maidah: 44-49. 
does not actually teach its followers to become a terrorist and spread the damage on earth.

So it is only political action, and a strategy to hide their mask from other Muslims; The act of terrorism is a false justification. In fact, Islam forbids its adherents to perform acts of "wrath" in the earth of Allah s.w.t, and Islam teaches its adherents to be a humble person (Q.S. 2: 190). In this context, acts of terrorism are dishonorable, even hated. Despite their actions aimed at fighting infidels. But Allah s.w.t has forbidden mu'min people to fight the heathen with sadistic action. Ironically, terrorists are constantly committed to their beliefs, or their vision to continue fighting non-Muslims, infidels like the United States and its colonies. In fact, Radical Muslims see that the people of the United States as idolaters. Quoting the Qur'an Muslim Radicals say and clarify the verses of the Qur'an.

Do you not notice those who claim to have believed in what was revealed to you and to what was revealed before you? They want to judge thaghut, but they have been ordered to deny the taghout. And shaitan intends to mislead them (with) the false apostasy ${ }^{47}$. I So for the sake of your Lord, they are not believers until they make you a judge of their disputed case, then they do not feel in their hearts an objection to the verdict you give, and they fully accept ${ }^{48}$.

The radical Muslim method of understanding the Qur'an is relatively similar to Wahhabism's method of interpreting the Qur'an-scriptural, and non-rational methods. This method was adopted by some radical Muslim groups in Indonesia. This adoption is a sign that Radical Muslims in Indonesia have parallelism in terms of doctrine, and patterns of action. Because of the doctrinal paradigm, the relationship between radical Islamic organizations can be understood. This assumption can be found in a research report published by the Congressional Research Service on the theme Terrorism in Southeast Asia. This report was written by several researchers. From this research it seems reasonable to ask the question: "How is the relationship of terrorism between one group with another group?". 
The largest terrorist group in the world is Al Qaeda led by Osama bin Laden. The group has a strong influence on terrorism networks in Southeast Asia. Informed in the early to mid-1990s, Al Qaeda has spread its influence in Southeast Asia. They operate in three processes. First, they build a local network, generally led by Al Qaeda members of Arab origin; This helps and supports regional terrorism networks ${ }^{49}$. Second, Al Qaeda Southeast Asia helps build and strengthen regional terrorism networks, such as Jemaah Islamiah, which are encouraged to fight the West. Jemaah Islamiah is responsible for the Bali bombing of October 12, 2002, which killed more than 200 people mostly tourists from Europe. Although "JI" is not a subordinate of Al Qaeda both collaborate intensively50. Third, Al-Qaeda collaborates with local Radical Islam by providing funding and training. With the help of Al Qaeda, terrorist network in Asia Tenggar grows strongly, and spreads massively. In Indonesia, this fact is still disputed. Does the Al Qaeda cell appear, and survive in Indonesia or not at all51? Radical Muslims are growing, especially their groups, in Indonesia certainly not the same as that developed in the Middle East. There is Imam Samudera, Umar Patek cell, and Amrozi network. The network is a particular movement, but it continues to grow and develop with the cadre system. It encourages a question: "It is true that terrorism cells in Indonesia are built without group intervention. It's hard to conclude that. There are facts that show that Al Qaedah and Jemaah Islamiah clearly influence some terrorist attacks in Indonesia.

From the CRS report for Congressional Research Service it can be seen that Al Qaedah provides funds and training operated by local groups in Indonesia, Malaysia, and the Philippines. Indonesian intelligence also saw, and proved that Al Qaedah sent support to participate in Muslim attacks against Christian groups in Maluku and Sulawesi in $2000^{52}$.

49 Thats cells have exploited the region's generally loose border controls to hold meeting in Southeast Asia to plan attacks against Western targets, host operatives transiting through Southeast Asia, and provide safe haven for other operatives fleeing U.S. intelligence service. See Bruce Vaughn, et.al., Terrorism in Southeast Asia, (CRS report for Congressional Research Service: October 16, 2009), p. 2.51 Ibid.

52 Ibid., p. 3.

52 Ibid. 
Another fact that informs the existence of terrorism relations in Indonesia is the influence of "JI" on local groups of Muslim radicals in Indonesia . In fact, extensive relationships are referred to as secret relationships. No other because the relationship built by Jemaah Islamiah is a relationship that is completely hidden, secretive. How is this understood?

The assassination of Noordin M. Top by the Indonesian government in 2009 is proof that the "JI" network has grown in Indonesia53. Not exaggerated, some analysts believe "JI" is not a regional organization, but it is administratively capable of reaching the territory of Indonesia as a whole ${ }^{54}$. In this context it seems reasonable to ask the question: Why does terrorism appear in many countries, and combat the West-US and its coalition? "The act of terrorism is an ideological movement. They appear to assert that Islam is capable of fighting with the Western ideologycapitalism and neo-liberalism. Lorenzo Vidino analyzes that the escalation of terrorism is a combination of several factors: 1) The failure of the immigration policy that enabled the rise of radical Islam in Europe; 2) Radicalism is a part, the inevitability of growing Muslim populations and strengthening their bergeling position; 3) The failure of Europe ensures a decent life for the world's poor, especially for the European region itself 55 . It is the European perspective whereas in the perspective of developing countries, the emergence of terrorism is caused by socioeconomic factors.

Discrimination and exploitation by neo-colonialism is a factor why terrorism arises. For terrorism, these factors are the result of a crime creation. That, in their reason, must be destroyed and abolished. Stephen Nathason thinks that terrorism attacks are part of a crime, the victims are innocent people who do not respond to this crime ${ }^{56}$. At least terrorism

\footnotetext{
53 Ibid.

55 Ibid., p. 4.

56Ibid.
}

56 Stephen Nathanson, Terrorism and the Ethic of War, (New York: Cambridge University Press, 2010), p. 41.

58 Cihan Tuğal, Passive Revolution: Absorbing The Islamic Challenge to Capitalism, (California: Stanford University Press, 2009), p. 19.

59 Jonathan Purkis, \& James Bowen (eds), Changing Anarchism, (New York: Manchester University Press, 2004), p. 23. 
has two sides: psychology and ideology. The ideological side are the socio-economic factors that drive the wildness of terrorism, and encourage them to become anarchists. For terrorism, sadistic acts are a reward for the exploitation of Kapiralism and Neo-liberalism in Muslim countries. Cihan Tugal understands that almost all Islamic movements are part of the traumatization caused by Westernization over the Muslim cultural traditions ${ }^{57}$, juha as a representation of the immorality of the ummah caused by the great ideology-Capitalism and Neo-liberalism. Thus, at least that view confirms that the appearance of terrorism is part of ideological conflict with big ideology. No doubt, the movement is defined as the class struggle in Islam. But their patterns and methods are wrong; There is no normative foundation in Islam.

\section{Conclusion: Cultural Movement and Anticipation of Terrorism}

Anticipation and abolition of terrorism in Indonesia tends to use the power of meliter and street violence. The legitimate government only considered that the move was a success. But the roots of terrorism will never be eliminated. In fact, terrorism is a social anarchism. In the sense that terrorism and the growing network of it in various countries are driven by socio-economic factors. Dave Morland argues: "Social anarchism is a long and long phenomenon as a disparation and incoherent ideology58." It encourages the understanding that terrorism is a complex phenomenon. It can not be justified, and judged by partial perspective, and sentimental conjecture. Fenoeman terrorism, does not contain three meanings: anti-semismism; Westernphobia; And jihad.

Gabriele Marranci in his book Jihad Beyond Islam notes that the Palestinian-Israeli conflict has spurred a wave of anti-Semitism ${ }^{59}$. At the other end, the massiveness of capitalism and neo-liberalism is complete with its exploitation, and discrimination in the economic structure leads to anti-western movements. This condition allows the widespread use of the doctrine of jihad to stir up hatred against Western civilization. Internalization of the doctrine is carried out by terrorism networks in various places or countries so it is difficult to anticipate terrorism with a

60 Gabriele Marranci, Jihad beyond Islam, (New York \& Oxford: Berg, 2006), p. 139. 
melitious approach. The doctrinal process is followed by a strong ideological cultivation. These assumptions and views encourage the formulation of efforts to anticipate terrorism by teaching Islamic values and correct concepts of jihad through the cultural movement or pesantren education.

\section{Bibliorgaphy}

Azra, Azyumardi, Surau: Surau: Pendidikan Islam Tradisional dalam Transisi dan Modrenisasi, terj. Idin Rasyidin dari; The Rise and Decline of the Minangkabau: A Traditional Islamic Education in West Sumatera During the Duch Colonial Government, Jakarta: PT Logos Wacana Ilmu, 2003.

Boechari, Sidi Ibrahim, Pengaruh Timbal Balik antara Pendidikan Islam danPergerakan Nasional di Minangkabau, Jakarta: Gunung Agung, 1981.

Crow, and Crow dalam Oemar Hamalik, Pembinaan Pengembangan Kurikulum, Bandung: Pustaka Martina, 1987.

Dahlan, Abdul Aziz dkk., (ed.), Ensiklopedi Hukum Islam,Jakarta: PT Ichtiar Baru Van Hoeve, 1999.

Daradjat, Zakiah Daradjat, Ilmu Jiwa Agama, Jakarta: Bulan Bintang, 1991.

Dobbin, Christine, "Islamic Revivalism in a Changin Peasent Economy Central Sumatra, 11784-1847, Terj. Lilian D. Tedjasudana, judul terjemahan, Kebangkitan Islam dalam Ekonomi Petani yang Sedang Berobah, Sumatera Tengah, 1784-1847, Jakarta: INIS, 1992.

Fadjar, A. Malik, Holistika Pemikiran Pendidikan, edit. Ahmad Barizi, Jakarta: Raja Grafindo Persada, 2005.

Gazalba, Sidi, Masjid Pusat Ibadat dan Kebudayaan Islam, Jakarta: Pustaka Antara, 1983.

Ghunaimah, Muhammad Abdu Rahim, tarikh al-Jami'at al-Islamiyah al-Kubra, Maroko: Dar al-Ittiba'ah al-Maghribiyah, 1953.

Graves, Elizabeth E., "Minangkabau Respon to Dutch Colonial Rule Nineteenth Century," (New York: 1981. terj. Mestika Zed, Reaksi Minangkabau terhadap Kolonialisme Belanda Abad XX, Padang: IKIP, 1986.

Hamalik, Omar, Perencanaan Pengajaran Berdasarkan Pendekatan Sistem, Jakarta: PT. Bumi Aksara, 2002.

Kaufman, Roger A, Educational System Planning, Englewood Cliffts, NMj: Prentice-Hall. INC., 1972

Kemal, Iskandar, "Beberapa Aspek dari Hukum Kewarisan Matrilineal ke Bilateral di Minangkabau,'dalam, Beberapa Studi tentang Minagkabau: Kumpulan Karangan, Padang: FHUK Unand, 1971. 
Latief, Sanusi, "Perkembangan Pemikiran Islam di Minangkabau" dalam Panji Masyarakat, No. 628, 1 November 1989.

Lindgren, Henry Clay, and W. Newton Suter, Education Psycology in The Classroom, California, Monterey: Brooks/Cole Publishing company, 1985.

Majolelo, Darwis Datuk., dan Ahmad Marzuki, Tuanku Imam Bojol Perintis Jalan Kemerdekaan, Jakarta:Yayasan Obor Indonesia, 1987.

Nain, Syafnir Aboe, Tuanku Imam Bonjol: Sejarah Intelektual Islam di Minangkabau, 1784-1832, Padang: Penerbit Esa, 1988

Nasution, Harun Pembaharuan dalam Islam, Sejarah Pemikiran dan Gerakan, Jakarta: Bulan Bintang, 1975.

Nizar, Samsul, Sejarah dan Pergolakan Pemikiran Pendidikan Islam; PotretTimur Tengah Era Awal dan Indonesia, Ciputat: Quantum Teaching, 2005.

-------, Sejarah Pendidikan Islam,; Menulsusuri Jejak Sejarah Pendidikan Era Rasulullah sampai Indonesia, Jakarta: Kencana Prenada Media Group, 2007.

-------, Seabad Buya Hamka; Memperbincangkan Dinamika Intelektual, dan Pemikiran Hamka tentang Pendidikan Islam, Jakarta: Kencana Prenada Media Group, 2008

------,Renungan Pemikiran dan Falsafah Hidup Hamka, Padang,: Makalah disampaikan pada Seminar Seabad Buya Hamka di Museum Aditiyawarman, 16 Februari 2008.

Noer, Delier, Gerakan Modern di Indonesia 1900-1942, Jakarta: LP3ES, 1996.

Prasodjo, Sudjoko, dkk. (ed.), Profil Pesantren, Jakarta: LP3ES, 1974.

Rais, Kamardi, "Surau dalam Pengembangan Masyaraka Nagari," makalah dalam Seminar dan Lokakarya (Semiloka), Kembali ke Surau, Padang: Hotel Bumi Minang, 27 Juni 2001.

Rajab, Muahamad, Perang Paderi di Sumatera barat 1803-1883, Jakarta: P.P, dan K, 1954.

Pijper, G.F., Beberapa Aspek Kajian Islam di Indonesia, 1900-1950, Bandung: Mizan, 1990.

Ramayulis dan Samsul Nizar, Ensiklopedi Tokoh Pendidikan Islam, Ciputat: Quantum Teaching, 2005.

Ridwan, Kafrawi, dkk. (ed.), Ensiklopedi Islam, Jakarta: PT Ichtiar Baru van Hoeve, 1994.

Steenbrink, Karel A., Pesantren, Madrasah dan Sekolah: Pendidikan Islam dalam Kurun Modern, Jakarta: LP3ES, 1994.

-------, Beberapa Aspek tentang Islam di Indonesia Abad ke-19, Jakarta, 1984

Usman, Zubir, Kedudukan Bangsa dan Bahasa Indonesia, Jakarta: Gunung Agung, 1960. 